\section{SOI: $1.1 /$ TAS DOI: $10.15863 / \mathrm{TAS}$ \\ International Scientific Journal Theoretical \& Applied Science}

\author{
p-ISSN: 2308-4944 (print) e-ISSN: 2409-0085 (online) \\ Year: $2018 \quad$ Issue: 09 Volume: 65
}

Published: $24.09 .2018 \quad$ http://T-Science.org

\author{
Amanay Tursunbaevna Akmatova \\ Candidate of Law, \\ acting Associate Professor of Department \\ of theory and history \\ of state and law of Osh state law institute
}

SECTION 32. Jurisprudence.

\title{
INDUSTRIAL SOVIET KYRGYZSTAN
}

Abstract: The machine building of the Kyrgyz Soviet Socialist Republic produced more than 200 types of products. Among the Central Asian Soviet socialist republics, Soviet Kyrgyzstan occupied the second place after Uzbekistan.

Key words: Osh Pumping Plant, economic region, subject of all - Union specialization, territorial division of labor, territorial - production complex.

Language: Russian

Citation: Akmatova AT (2018) INDUSTRIAL SOVIET KYRGYZSTAN. ISJ Theoretical \& Applied Science, 09 (65): 179-181.

Soi: http://s-o-i.org/1.1/TAS-09-65-32 Doi: crossef https://dx.doi.org/10.15863/TAS.2018.09.65.32

\section{ИНДУСТРИАЛЬНЫЙ СОВЕТСКИЙ КИРГИЗСТАН}

Аннотация: Машиностроение Киргизской Советской Сочиалистической Республики производило более 200 видов продукиии. Среди среднеазиатских советских соџиалистических республик Советский Киргизстан занимал второе место после Узбекистана.

Ключевые слова: Очский насосный завод, экономический регион, субъект общесоюзной спеииализации, территориальное разделение труда, территориально- производственный комплекс.

\section{Introduction}

Машиностроение

Советского Социалистического Киргизстана производила грузовые автомобили, насосы, газовые плиты. Были введены в действие специализированные заводы: Кайындынский кабельный, «Кыргызэлектродвигатель», «Тяжэлектромаш», Иссык-Кульское объединение электротехнических заводов, Майлуу-Сууский электроламповый завод. $\mathrm{B}$ отрасли автомобилестроения было построено 2 завода: «Кыргызавтомаш» и Фрунзенский (Бишкекский) автосборочный. Были введены в действие высокоспециализированные заводы: Ошский насосный и «Кыргызкабель» [2].

Машиностроение и металлообработка являлись субъектами общесоюзной специализации республики в межреспубликанском разделении труда. В системе общесоюзного территориального разделения труда Киргизская ССР специализировалась на развитии и производстве продукции цветной металлургии, машиностроения, электроэнергетики, хлопководстве [9].

\section{Materials and Methods}

Развитие экономики Киргизской ССР органически было связано с созданием эффективной системы территориального разделения труда и установлением рациональных хозяйственных связей Киргизии со всеми республиками СССР. Подавляющая часть промышленной продукции шла на удовлетворение потребностей всего СССР [3]. Их нормальное функционирование базировалось на поставках комплектующих деталей из других республик, на поставках продукции чёрной металлургии.

Причинами постепенного развития являлись следующие признака:

- экономическим районированием страны;

- рациональным размещением производительных сил;

- развитием экономики различных районов Союза ССР [4].

Так, территория СССР была подразделена на 19 экономических районов [10]. Каждый регион представляет собой мощный народнохозяйственный комплекс.

В Киргизской ССР выделялось 2 
экономических района - Северная Киргизия (районы республиканского подчинения Чуйской долины, Иссык - Кульская, Таласская и Нарынская области) и Южная Киргизия (Ошская область). Каждый из них выполняла определенную производственную функцию в хозяйственном строительстве.

На юге Киргизской Советской Социалистической Республики выделялось три экономических района: Ош-Джалал-Абадский, Нижне - Нарынский и Кадамждай Хайдаркенский.

Ош-Джалал-Абадский район представлял собой сложный по своей производственной структуре территориально - производственный комплекс, где ведущее значение имела легкая и пищевая промышленность, машиностроение, промышленность строительных материалов, хлопководство, табаководство и животноводство.

Ошский насосный завод находился в составе Министерства химического и нефтяного машиностроения СССР. Здание Ошского насосного завода находилось в городе Ош по улице Киргизстана 44 . Ошский насосный завод был основан как артель «Металлист» в 1939 году. Количество работающих составляло около 900 человек. На заводе работало 14 бригад, 8 отделов.

В 1946 г. - 1947 г. артель «Металлист» была преобразована в литейно-механическое предприятие.

В 1959 г. артель «Металлист» была объединена с мотороремонтным заводом (1947г.), В результате объединения образован электромеханический завод, выпускавший погружные скважинные насосы для воды.

Первая партия насосов типа АПВ была изготовлена в 1960 г.

В 1965г. насосный завод был передан Министерству химического и нефтяного машиностроения СССР и получил название Оиский насосный завод.

В 1968 г. была произведена первая реконструкция насосного завода. Так, на реконструкцию Оиского насосного завода в 1977 - 1978 годы Министерству химического и нефтяного машиностроения СССР предусматривалось выделение 3,7 млн. рублей капитальных вложений. Однако, Гос план Союза ССР реконструкцию завода исключил из плана 1977 года.

14 декабря 1977 году первый секретарь Ошского обкома партии Ибраимов Султан Ибраимович (Султан Ибраимович Ибраимов советский государственный и партийный деятель, Председатель Совета Министров Киргизской CСР (1978-80 гг.) [1]. Первый секретарь Ошского обкома КПСС.) написал Докладную записку [5] в ЦК КП Киргизии с ходатайством.
Ошский обком КП Киргизии убедительно просил ЦК КП Киргизии ходатайствовать перед Госпланом СССР, Минхиммашем по выделению средств на реконструкцию Ошского насосного завода в 1977 г. -1978 г.

Согласно Приказа № 248 от 24 ноября 1975 года Минхиммашем Ошскому насосному заводу предусматривалось выделение капитальных вложений в объеме 3,7 млн. рублей на реконструкцию в 1977 - 1978 годах [5, с. 158].

Во исполнение данного приказа институтом Гипрохимаш г. Алма - Ата была разработана проектно - сметная документация, которая была передана разработчику. Дополнительно была произведена подготовка площадки под строительство и снос жилых строений. На эти цели уже было израсходовано 243 тыс. рублей капитальных вложений.

К сожалению, Государственный план Союза ССР реконструкцию Ошского насосного завода исключил из плана 1977 года, а Управление капитального строительства Минхиммаша не выделено средств на капитальное строительство [8].

Участок Ошского насосного завода резинотехнических изделий и пластмасс, а также кузнечнопрессовый цех и инструментальный участок завода уже в 1976 году по использованию производственных площадей достиг своего предела и нуждался в реконструкции. Ошский обком КП Киргизии убедительно просил выделить токарные автоматы 1265 М в количестве трех штук и рулонную электротехническую сталь марки $30-100$ в количестве 300 тонн [5, с. 159].

Ошский насосный завод специализировался на выпуске насосов центробежных скважинных для воды с погружным электродвигателем типа ЭЦВ (более 42 тыс. шт. в год). Насосы были рассчитаны на работу в неагрессивной воде при температуре до $25^{\circ} \mathrm{C}$ с содержанием механических примесей не более $0,01 \%$ по весу. Насосы также применялись для городского, поселкового и сельскохозяйственного водоснабжения и для понижения уровня грунтовых вод [6].

Продукция Ошского насосного завода экспортировалась в Монголию, Ирак, Афганистан, Вьетнам, Лаос, Югославию, Мали, Алжир, Ливию и др. страны.

Кроме основной продукции, Ошский насосный завод производил товары народного потребления: бытовой насос «Ак-Буура», запчасти к насосам, алюминиевые казаны ёмкостью от 2 до 100 л, бытовые изделия из пластмассы - годовой объём выпуска этих товаров составляет (на 1 января 1986г.) 560 тыс. руб. или 5,5\% от общего объёма производства, который составляет около 10,9 млн. руб. в год [7]. 


\begin{tabular}{l|lr|ll|ll} 
& ISRA (India) & $=\mathbf{1 . 3 4 4}$ & SIS (USA) & $=\mathbf{0 . 9 1 2}$ & ICV (Poland) & $=\mathbf{6 . 6 3 0}$ \\
Impact Factor: & ISI (Dubai, UAE) $=\mathbf{0 . 8 2 9}$ & PUHЦ (Russia) $=\mathbf{0 . 1 5 6}$ & PIF (India) & $=\mathbf{1 . 9 4 0}$ \\
& GIF (Australia) & $\mathbf{0 . 5 6 4}$ & ESJI (KZ) & $=4.102$ & IBI (India) & $=\mathbf{4 . 2 6 0}$ \\
& JIF & $=\mathbf{1 . 5 0 0}$ & SJIF (Morocco) & $=2.031$ & & \\
\hline
\end{tabular}

Первый секретарь Ошского обкома партии Ибраимов Султан Ибраимович написал письмо - обращение Министру Химического и нефтяного машиностроения СССР Брехову Константину Ивановичу с просьбой выделить токарные автоматы $1265 \mathrm{M}$ в количестве трех штук и рулонную электро-техническую сталь марки 30-100 в количестве 300 тонн [5, с. 160].

\section{Conclusion}

После распада СССР все хозяйственные связи были потеряны. Многие предприятия были ликвидированы или разрушены. Ошский насосный завод был разрушен, все техническое оборудование было распродано.

\section{References:}

1. (1982) Entsiklopediya «Kirgizskaya SSR» Frunze, 1982g. -p.197.

2. Malabekov T. (1972) Razvitie sotsialisticheskoy industrii Kirgizii, Frunze 1972, 36 p.

3. Chyiymyilova B.D. (1977) Istoriya razvitiya sotsialisticheskogo sorevnovaniya v promyishlennosti Kirgizii, Frunze 1977, 296 p.

4. Selihova O.R. (1976) Regionalnyie osobennosti ekonomicheskogo razvitiya Kirgizii, Frunze , 1976,85 p.

5. (1970) Partiynyiy Arhiv Oshskogo OK KP Kirgizii Fond 2 Opis \# 106 Delo \#8, str 159.

6. (1970) Sovetskiy Soyuz. Kirgiziya. Izdatelstvo «Myisl» Moskva 1970.
7. (1982) Kirgizskaya Sovetskaya Sotsialisticheskaya Respublika. Entsiklopediya. Frunze $1982 \mathrm{~g}$.

8. (1987) Oshskaya oblast. Entsiklopediya. Frunze $1987 \mathrm{~g}$.

9. Lelchuk V.S. (1984) Industrializatsiya SSSR: istoriya, opyit, problemyi. - M.: Nauka, 1984. $304 \mathrm{p}$.

10. Deopik D.V. (1981) Nekotoryie printsipyi postroeniya formalizovannyih yazyikov dlya issledovaniya istoricheskih istochnikov // Kolichestvennyie metodyi $\mathrm{v}$ gumanitarnyih naukah / Pod red. I. D. Kovalchenko. - M.: Izdvo MGU, 1981. - p. 5-10. 